\title{
Nephrotoxicity of Herbal Medicine and Its Prevention
}

\author{
Xiaofen $\mathrm{Xu}{ }^{1}$, Ruyi Zhu ${ }^{1}$, Jialiang Ying ${ }^{1}$, Mengting $\mathrm{Zhao}^{2}$, Xin $\mathrm{Wu}^{1}$, Gang $\mathrm{Cao}^{1 *}$ \\ and Kuilong Wang ${ }^{1 *}$ \\ ${ }^{1}$ School of Pharmacy, Zhejiang Chinese Medical University, Hangzhou, China, ${ }^{2}$ School of Pharmacy, Guizhou University \\ of Traditional Chinese Medicine, Guiyang, China
}

Herbal medicine $(\mathrm{HM})$ has been widely used to treat diseases for thousands of years and has greatly contributed to the health of human beings. Many new drugs have been developed from HM, such as artemisinin. However, artemisinin has adverse effects, such as renal toxicity. In 1993, a study conducted in Belgium reported for the first time that the root extracts of Aristolochia obliqua S. M. Hwang led to progressive interstitial renal fibrosis. The nephrotoxicity of HM has attracted worldwide attention. More than 100 kinds

OPEN ACCESS

Edited by:

Karl Tsim,

Hong Kong University of Science and Technology, Hong Kong

Reviewed by:

Yanfei Liu,

Beijing University of Chinese Medicine,

China

Xufeng Tao,

Dalian University of Technology, China

*Correspondence:

Kuilong Wang

wangkuilong89@163.com

Gang Cao

caogang33@163.com

Specialty section:

This article was submitted to

Ethnopharmacology,

a section of the journal

Frontiers in Pharmacology

Received: 05 June 2020 Accepted: 14 August 2020 Published: 15 October 2020

Citation:

Xu X, Zhu R, Ying J, Zhao $M$,

Wu X, Cao G and Wang K (2020)

Nephrotoxicity of Herbal

Medicine and Its Prevention.

Front. Pharmacol. 11:569551. doi: 10.3389/fphar.2020.569551 of HM induce renal toxicity, including some herbs, animal HMs, and minerals. This paper aimed to summarize the HM compounds that cause nephrotoxicity, the mechanisms underlying the toxicity of these compounds, biomarkers of renal injury, and prevention strategies. These findings provide a basis for follow-up studies on the prevention and treatment of HM nephrotoxicity.

Keywords: herbal medicine, nephrotoxicity, toxic components, toxicity mechanism, prevention strategies

\section{INTRODUCTION}

With the extensive use and deepening pharmacological research on HM, the adverse effects of HMs have also been determined. HM differs from western medicine, its side effects are considered slight, and it can be taken for a long time or at a large dose. However, in recent years, reports of adverse reactions caused by HM and its preparations have increased every year. Nephrotoxicity is one of the main toxicities of HMs. In the 1960s, some scholars first reported the cases of acute renal failure caused by the administration of Aristolochia manshuriensis Kom in China, after which relevant reports also appeared abroad (Wu, 1964). In 1993, Belgian scholars reported that nine European women suffered from renal failure after taking weight-loss capsules containing Chinese herbal medicine A. obliqua S. M. Hwang; this condition is called "Chinese herb nephropathy (CHN)" (Vanherweghem et al., 1993).

Besides aristolochic acid, many other HM components cause renal toxicity. Severe renal tubular lesions have been found in renal puncture examinations of patients with kidney disease caused by Tripterygium regelii Sprague. et. Takeda. The lesions are accompanied by obvious inflammatory cell infiltration, degeneration, and necrosis of renal tubular epithelial cells (Luo et al., 2018b). The administration of a large amount of Glycyrrhiza uralensis Fisch. caused rhabdomyolysis and acute renal injury. Many kinds of animal HMs can cause renal toxicity, such as Scolopendra subspinipes mutilans L. Koch, fish gall, and Mylabris. Fish gall can cause the swelling and necrosis of renal tubular epithelial cells and medullary edema. Hirudo nipponica Whitman and S. subspinipes mutilans L. Koch may lead to hemolytic reaction, aggravating the damage to renal function and 
eventually leading to massive hematuria. Realgar, a mineral Chinese medicine, directly injures the glomerulus. In summary, according to research statistics, more than 100 kinds of HM have toxic effects on the kidney. This article focuses on the kidney toxicity of HMs and their possible mechanisms and summarizes the strategies for preventing HM nephrotoxicity.

Statistics state that more than 100 kinds of HM preparations can cause kidney damage. With the popularization of Chinese culture, HM has also become gradually known and exported to South Korea, Japan, India, Germany, and other European countries, thus playing a huge role in the world medical system (Wang, 2013). Therefore, improving the understanding of HM drugs with renal toxicity effects has become an urgent problem. In this paper, HM drugs with renal toxicity were discussed in accordance with their types of toxic components. Moreover, the causes of kidney injury and the toxicity mechanisms of components were introduced in detail. The measures to reduce renal toxicity were elaborated upon at length on the basis of modern science and technology. This elaboration is conducive to follow-up studies on the prevention and treatment measures of $\mathrm{HM}$ and the safety of clinical medication.

\section{COMPOUNDS LIABLE FOR NEPHROTOXICITY AND REPRESENTATIVE HM}

\section{Organic Acids}

Organic acid is an organic compound (excluding amino acid) that contains a carboxyl group. This compound widely exists in plants. Aristolochic acid (1) is the most representative nephrotoxic component among the HM organic acids, and its representative HMs are A. manshuriensis Kom, A. obliqua S. M. Hwang, and $A$, debilis Sieb. Et Zucc. Aristolochic acid can cause necrosis and apoptosis of renal tubular epithelial cells.

\section{Alkaloids}

Alkaloid is a nitrogen-containing organic compound that exists in nature and is obtained from plants. It is a toxic component of many HMs, such as matrine (2) and genistein in Sophora flavescens Ait., glycoside alkaloid in Alisma orientale (Sam.) Juzep., arecoline (3) in Areca catechu L., and colchicine (4) detected in Gremastra appendiculata (D. Don) Makino. Other examples are Tetrandrine (5), Ephedrine (6), Leonurine (7). Most types of nephrotoxic alkaloid are organic amines, pyrrolidines, pyridines, and isoquinolines.

\section{Terpenes and Lactones}

Terpenoids and lactones are ubiquitous compounds in the plant kingdom. Terpenoids are derivatives with a general formula of $\left(\mathrm{C}_{5} \mathrm{H}_{8}\right)_{n}$, oxygen content, and different saturation degrees. Lactone is an organic compound with one ester group formed by the esterification of one molecule. They have important physiological activities and are important resources for the research of natural products and the development of new drugs. This kind of nephrotoxic component includes cinnamaldehyde
(8), thujone (9) and triptolide (10). Representative HMs include Cinnamomum cassia Presl, Magnolia officinalis Rehd. et Wils., Melia toosendan Sieb.et Zucc., and Leonurus japonicus Houtt., and the nephrotoxicity of these substances is weaker than that of aristolochic acid. In clinical use, doctors often focus on its efficacy and ignore its toxicity. This substance can cause renal tubulointerstitial damage, the sufferers of which may show symptoms of uremia and proteinuria.

\section{Toxic Proteins}

A virulent protein is obtained from a normal cellular protein, $\mathrm{PrPc}$, which has been changed but does not have the function of a normal protein. It is the smallest known infectious medium with a single component. It is nearly only composed of protein, but without nucleic acid. It can strongly resist proteolytic enzymes. These toxic substances are obtained from protein components in animal and plant medicinal materials, such as trichosanthin in Trichosanthes kirilowii Maxim, histamine-like substance hemolytic protein in S. subspinipes mutilans L. Koch, and leech protein in Hirudo nipponica Whitman.

\section{Minerals}

Most of the toxic components of minerals contain heavy metals, which include arsenic, mercury, and lead. The representative drugs are $\mathrm{Ae}_{2} \mathrm{~S}_{2}$ in Realgar, $\mathrm{HgS}$ in cinnabaris, and $\mathrm{Pb}$ in Red lead. After taking these drugs in large quantities, heavy metals accumulate in the kidneys because of metabolic difficulties, resulting in kidney damage. For example, cinnabars accumulate in the kidney and lead to the apoptosis of renal tubular epithelial cells in the renal cortex.

\section{Flavonoid Glycosides}

Flavonoid glycosides are widely found in plants and berries with strong antioxidant properties. Even low amounts of flavonoid glycosides cause kidney damage in HM. Some of these flavonoid glycosides come from dry mature seeds of Ginkgo biloba, the toxic component of which is ginkgo neuter. Flavonoid glycosides are a series of compounds formed by the interconnection of two benzene rings (A- and B-rings) with phenolic hydroxyl groups through the central three carbon atom. Their basic parent nucleus is 2-phenylchromogenic ketone.

\section{Saponins}

Saponin is a plant glycoside that can form colloid solution and soap-like foam. The representative HMs containing saponins are Xanthium sibiricum Patr., Bupleurum chinense DC., Clematis chinensis Osbeck, and Pulsatilla chinensis (Bge.) Regel. In addition to Pulsatilla chinensis (Bge.) Regel, the toxic component of $C$. chinensis Osbeck is also anemonin (11). Long-term administration of $C$. chinensis Osbeck lead to acute renal tubular injury, necrosis, or chronic interstitial nephritis. Other components with nephrotoxicity are saikosaponin A (12), geniposide (13), esculentoside A (14). Saponins are glycosides composed of aglycones and sugars, glucuronic acids, or other organic acids. According to the known molecular structure of aglycones, the saponins of c-27 steroids are called steroids and those of triterpenoids are called triterpenoids. 
According to statistics, more than 100 kinds herbs may cause kidney toxicity in HM, and their toxic components are not fully understood. In addition to the representative toxic compounds listed above, anthraquinones in Polygonum cuspidatum Sieb.et Zucc. are toxic components, and the main toxic components in rhubarb are emodin (15), aloe emodin (16) and other anthraquinones. The toxic component of Eugenia caryophyllata Thunb. is eugenol (17), which is an aromatic compound. Aloin (18) is a nephrotoxic component in Aloe barbadmsis Miller. The toxic components of fish gall, such as histamine or oxide, are complex. Other known nephrotoxic HMs such as Schizonepeta tenuifolia Briq., Bolbostemma paniculatum (Maxim.) Franquet, Euphorbia pekinensis Rupr., and Eugenia caryophyllata Thunb. These need further experimental analysis to determine their toxic components. Table 1 shows the HM nephrotoxicity and their toxic ingredients. Figure $\mathbf{1}$ shows the representative structure of nephrotoxic components.

\section{NEPHROTOXIC MECHANISMS}

Different drugs can cause varied damage to the kidney. Hence, detection indicators are different and reflect the differentially damaged kidney parts. The damage of HM to the kidney is very complex. Thus, it is necessary to use as many indicators as possible to reflect the damage site and infer the mechanism of action. In 2008 and 2010, the U.S. Food and Drug Administration and the
European Drug Administration accepted the application of PSTC and HESI and recognized eight kinds of nephrotoxic biomarkers, namely, clusterin, urinary total protein (uTP), $\beta 2$-microglobulin $(\beta 2-\mathrm{MG})$, cystatin $\mathrm{C}$, kidney injury molecule (Kim-1), trefoil factor3 , albumin, and renal papillaryantigen-1. These eight markers are used for drug preclinical and clinical safety evaluations. In addition, renal toxicity has many other indicators, such as NGAL, interleukin, microproteinuria, NAG, $\alpha$-GST, and organic anion transporters, which can be used to detect the degree of renal injury. In this paper, according to the course of the disease and the above indicators, we divided the nephrotoxicity of HM into two categories for clarity, namely, chronic and acute toxicities. Table 2 shows the markers that can be used to detect kidney damage.

\section{Chronic Toxicity}

\section{Mechanism Related to Apoptosis}

Cinnabaris contains the heavy metal mercury; the long-term use of cinnabars can cause the accumulation of mercury in the kidneys and cause kidney damage (Wang et al., 2015b). Clinically, acute renal function damage is often caused by the misuse of a large dose of cinnabaris, and chronic renal function damage is caused by taking a single or compound preparation for a long time as part of an excessive or conventional dose.

Cinnabaris can induce the apoptosis of renal tubular epithelial cells, and this pathway may be an important mechanism for subchronic nephrotoxicity. The apoptosis signaling pathway mediated by death receptor may be an

TABLE 1 | Chinese herbal medicines known to contain kidney toxicity components.

\begin{tabular}{|c|c|c|c|}
\hline Latin name & English name & Nephrotoxiccompounds & References \\
\hline Aristolochiaceae & Aristolochic & Aristolochic acid & (Lv et al., 2012) \\
\hline Aristolochia manshuriensis Kom & Manshuriensis & Aristolochic acid & (Lv et al., 2012) \\
\hline Aristolochia obliqua S. M. Hwang & Fangchi & Aristolochic acid & (Lv et al., 2012) \\
\hline Aristolochia debilis Sieb. et Zucc. & Radix aristolochiae & Aristolochic acid & (Lv et al., 2012) \\
\hline $\begin{array}{l}\text { Asarum heterotropoides Fr. } \\
\text { Schmidt var. Mandshuricum } \\
\text { (Maxin.) Kitag. }\end{array}$ & Asarum sieboldii & Aristolochic acid & (Lv et al., 2012) \\
\hline Aristolochia cinnabarina & Root of Kaempfer & Aristolochic acid & (Lv et al., 2012) \\
\hline C. Y. Cheng et J. L. Wu & Dutchmans pipe & & \\
\hline $\begin{array}{l}\text { Aristolochia mollissima } \\
\text { Hance. }\end{array}$ & Aristolochia & Aristolochic acid & (Lv et al., 2012) \\
\hline Sophora flavescens Ait. & Sophora flavescens & Matrine & (Weng et al., 2018) \\
\hline Leonurus ja ponicus Houtt. & Motherwort & Leonurine & (Huang and Sun, 2010) \\
\hline Arecacatechu L. & Betelnutpalm Seed & Arecoline & (Zeng et al., 2015) \\
\hline Cinnamomum cassia Presl & Cinnamon Bark & Cinnamaldehyde & (Zhang et al., 2019) \\
\hline $\begin{array}{l}\text { Melia toosendan Sieb.et } \\
\text { Zucc. }\end{array}$ & Toosendan Fruit & Toosendanin & (Li et al., 2017) \\
\hline $\begin{array}{l}\text { Tripterygium regelii } \\
\text { Sprague. et Takeda. }\end{array}$ & Tripterygium Root & Triptolide & (Xi et al., 2017) \\
\hline $\begin{array}{l}\text { Trichosanthes kirilowii } \\
\text { Maxim. }\end{array}$ & $\begin{array}{l}\text { Mongolian Snakegourd } \\
\text { Root }\end{array}$ & Trichosanthin & (Jiao et al., 2014) \\
\hline Croton tiglium L. & Croton & Crotin & (Jiao et al., 2014) \\
\hline Xanthium sibiricum Patr. & Xanthium Fruit & Xanthotoxin & (Jiao et al., 2014) \\
\hline RicinuscommunisL. & Castor Seed & Ricin & (Jiao et al., 2014) \\
\hline / & Realgar & $\mathrm{Ae}_{2} \mathrm{~S}_{2}$ & (Jiao et al., 2014) \\
\hline / & Cinnabaris & $\mathrm{HgS}$ & (Jiao et al., 2014) \\
\hline Phytolacca acinosa Roxb. & Pokeberry Root & Esculentoside A & (Yang X. et al., 2019) \\
\hline Gardenia jasminoides Ellis & Gardenia & Geniposide & (Feng et al., 2016) \\
\hline Rheum palmatum L. & Rhubarb & Emodin & (Hu et al., 2019) \\
\hline Pulsatilla chinensi(Bge.)Regel & Anemone & Anemonin & (Jiao et al., 2014) \\
\hline
\end{tabular}


<smiles>CC(C)C1CC2CCCC2C2C(C)C3CCCC3CC12</smiles>

1

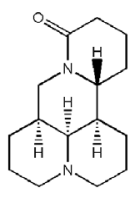

2<smiles>COC(=O)C1=CCCN(C)C1</smiles>

3<smiles>CN[C@@H](C)[C@H](O)c1ccccc1</smiles><smiles>COc1cc2c(c(OC)c1OC)-c1ccc(OC)c(=O)cc1C(NC(C)=O)CC2</smiles>

4

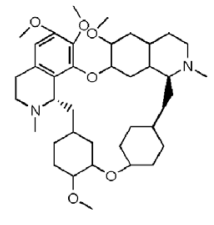

5<smiles>COc1cc(C(=O)OCCCCNC(=N)N)cc(OC)c1O</smiles>

7<smiles>O=CC=Cc1ccccc1</smiles>

8<smiles>CC1C(=O)C[C@@]2(C(C)C)C[C@]12C</smiles>

9

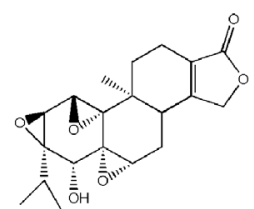

10<smiles>O=C1C=CC2(CCC3(CCC3)S2)S1</smiles>

11

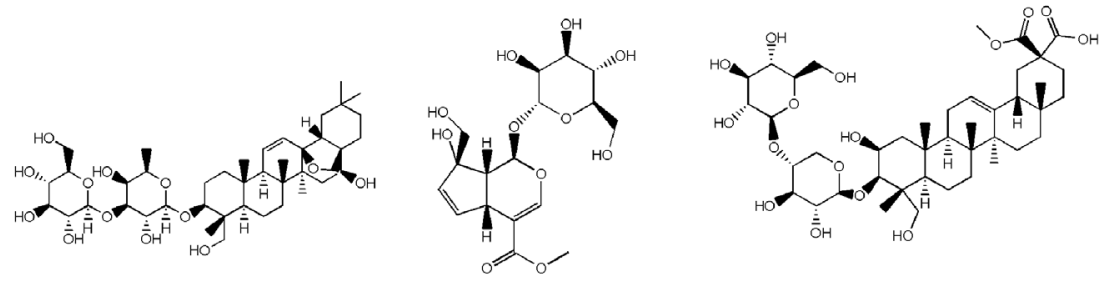

12<smiles>Cc1cc(O)c2c(c1)C(=O)c1cc(O)cc(O)c1C2=O</smiles>

15<smiles>O=C1c2cccc(O)c2C(=O)c2c(O)cc(CO)cc21</smiles>

16<smiles>C=CCc1ccc(O)c(OC)c1</smiles>

17
14

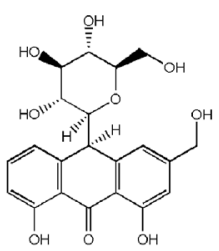

18

FIGURE 1 | Representative nephrotoxic compounds structures.

important pathway for cinnabaris to induce apoptosis of renal tubular epithelial cells (Wang et al., 2015a). The application of mercury containing the drug wuwudan in large doses can cause the apoptosis of renal cells by regulating the expression levels of Bax/Bcl-2 apoptosis-related proteins (Li and Pan, 2012).

In addition to the above-mentioned mechanisms, mercury can induce apoptosis through the mitochondrial-mediated endogenous pathway. This process will increase the content of free radicals in the mitochondria, change the activity of protease on mitochondrial membrane, improve the permeability of mitochondrial membrane, affect the synthesis of ATP, and lead to the release of cytochrome C. After entering the cytoplasm, cytochrome $\mathrm{C}$ enhances the oxidation of cells and then induces cell apoptosis (Gao et al., 2009).

After 2 weeks, the administration of $80 \mu \mathrm{mol} \cdot \mathrm{L}^{-1}$ of emodin can inhibit the proliferation of HK-2 cells, promote cell apoptosis, and decrease mitochondrial membrane potential. Its mechanism is that emodin inhibits the phosphorylation of 
TABLE 2 | Nephrotoxic biomarkers.

\begin{tabular}{|c|c|c|c|}
\hline Biomarkers & Injury sites & Feature & Reference(s) \\
\hline clusterin & $\begin{array}{l}\text { Proximal convoluted tubule; } \\
\text { distal convoluted tubules; } \\
\text { collecting duct }\end{array}$ & $\begin{array}{l}\text { increased with high sensitivity in the preclinical } \\
\mathrm{AKI} \text { model, up regulated expression in AKI, } \\
\text { renal fibrosis, renal cell carcinoma and other } \\
\text { models }\end{array}$ & (Vinken et al., 2012) \\
\hline UTP & glomerulus & $\begin{array}{l}\text { predicted early glomerular injury sensitively } \\
\text { and specifically, widely used in the prevention } \\
\text { and monitoring of kidney diseases in clinical } \\
\text { research }\end{array}$ & (Peterson et al., 1969) \\
\hline$\beta 2-M G$ & $\begin{array}{l}\text { Proximal convoluted tubule; } \\
\text { glomerulus }\end{array}$ & $\begin{array}{l}\text { the monomer form of it can be filtered through } \\
\text { glomerulus and reabsorbed by proximal } \\
\text { convoluted tubular cells; limited in clinical } \\
\text { application due to its instability in acidic urine }\end{array}$ & (Schaub et al., 2005) \\
\hline cystatin C & $\begin{array}{l}\text { Proximal convoluted tubule; } \\
\text { glomerulus; distal convoluted } \\
\text { tubules; collecting duct }\end{array}$ & $\begin{array}{l}\text { passed glomerular filtration and reabsorbed by } \\
\text { proximal convoluted tubular cells; reflected } \\
\text { renal tubular dysfunction due to its increase in } \\
\text { urine }\end{array}$ & $\begin{array}{l}\text { (Waring and Moonie, 2011; de Geus } \\
\text { et al., 2012; Pianta et al., 2017) }\end{array}$ \\
\hline Kim-1 & Proximal convoluted tubule & $\begin{array}{l}\text { used in preclinical and clinical acute renal } \\
\text { injury studies, up regulated expression in AKI, } \\
\text { renal fibrosis and other preclinical and clinical } \\
\text { models }\end{array}$ & $\begin{array}{l}\text { (Ichimura et al., 2008; Waring and } \\
\text { Moonie, 2011; de Geus et al., 2012) }\end{array}$ \\
\hline TFF-3 & Proximal convoluted tubule & $\begin{array}{l}\text { mainly expressed in intestinal and renal tissues, } \\
\text { increased expression and activity in ulcer tissue }\end{array}$ & (Xing et al., 2013; Wang et al., 2019) \\
\hline albumin & $\begin{array}{l}\text { Proximal convoluted tubule; } \\
\text { glomerulus }\end{array}$ & $\begin{array}{l}\text { also increased expression in the state of } \\
\text { inflammation, bleeding, urinary tract } \\
\text { infections, fever or stress. not a specific index } \\
\text { of nephrotoxicity, needs to be combined with } \\
\text { other markers }\end{array}$ & $\begin{array}{l}\text { (Schött et al., 2018; Luo et al., } \\
\text { 2018a; Fernández et al., 2019) }\end{array}$ \\
\hline RPA-1 & collecting duct & $\begin{array}{l}\text { predicted the early toxicity of renal papilla } \\
\text { and has a good correlation with the degree of } \\
\text { renal papilla injury }\end{array}$ & (Betton et al., 2012) \\
\hline NGAL & renal tubule; collecting duct & $\begin{array}{l}\text { considered to be a good marker of acute renal } \\
\text { injury, and also a powerful early marker to } \\
\text { assist the diagnosis of AKI and CKD. Increased } \\
\text { the serum NGAL level in the state of } \\
\text { inflammation and infection }\end{array}$ & $\begin{array}{l}\text { (Waring and Moonie, 2011; de Geus } \\
\text { et al., 2012; Avci Çiçek et al., 2016; } \\
\text { Wang et al., 2015a) }\end{array}$ \\
\hline NAG & Proximal convoluted tubule & $\begin{array}{l}\text { cannot be filtered by glomeruli and increased in } \\
\text { the urine derives from tubular damage } \\
\text { increased expression in urine is associated with } \\
\text { poor prognosis of AKI }\end{array}$ & $\begin{array}{l}\text { (Waring and Moonie, 2011; de Geus } \\
\text { et al., 2012) }\end{array}$ \\
\hline IL-18 & Proximal convoluted tubule & $\begin{array}{l}\text { a cytokine with extensive immunoregulation, } \\
\text { especially in the process of ischemic injury; } \\
\text { considered its increased expression in urine as the } \\
\text { early marker of } \mathrm{AKI} \text { and the death signal of clinical } \\
\text { critically ill patients }\end{array}$ & (de Geus et al., 2012) \\
\hline L-FABP & renal tubule & $\begin{array}{l}\text { considered the appearance of urinary L-FABP } \\
\text { as a powerful sign in AKI induced by ischemic } \\
\text { and nephrotoxin }\end{array}$ & $\begin{array}{l}\text { (Yamamoto et al., 2007; de Geus } \\
\text { et al., 2012) }\end{array}$ \\
\hline $\begin{array}{l}\text { IGFBP7/ } \\
\text { TIMP2 }\end{array}$ & / & $\begin{array}{l}\text { related to cell cycle arrest, and proved to be } \\
\text { useful biomarkers of } \mathrm{AKI} \text {, but still need to be } \\
\text { further verified }\end{array}$ & $\begin{array}{l}\text { (Kashani et al., 2013; Verhagen } \\
\text { et al., 2014; Bihorac et al., 2014; } \\
\text { Gocze et al., 2015) }\end{array}$ \\
\hline
\end{tabular}

extracellular signal regulated kinase $1 / 2\left(\mathrm{ERK}_{1 / 2}\right)$ and the expression of Bcl-2 in $\mathrm{HK}-2$ cells. However, Bax does not undergo obvious changes, leading to the dominance of proapoptotic gene proteins, the development of cells towards proapoptosis, and the increase in the release of cytochrome $c$, thereby activating caspase- 8 and downstream caspase- 3 and causing apoptosis (Wang et al., 2010).

\section{Mechanism of Oxidative Damage}

The long-term administration of total alkaloids of Leonurus ja ponicus Houtt. leads to obvious oxidative damage and renal toxicity in rats (Sun, 2017). This condition may be caused by the large amount of reactive oxygen species (ROS) produced by the body after the drug acts on the kidney, thus directly damaging the kidney cells. The possible mechanism may be as follows: ROS reacts with the macromolecular substances of the cell membrane to form lipid peroxide, thus damaging the oxidative phosphorylation process, making the energy metabolism abnormal, and finally leading to abnormal mitochondrial function, reduced SOD and XOD secretion, cell damage, and apoptosis (Huang and Sun, 2010).

Rheum palmatum L. and its anthraquinone compounds can cause renal damage under certain conditions (Yan et al., 2006; 
Liu et al., 2017; Deng et al., 2018). The main toxic components of R. palmatum L. are rhein, emodin, and aloe emodin. The longterm administration of $R$. palmatum $\mathrm{L}$. causes certain toxicity to the kidney of mice (Hu et al., 2019). At a dose of $0.35 \mathrm{~g} \cdot \mathrm{kg}^{-1} \cdot \mathrm{D}^{-1}$, the toxicity is obvious, and a significant gender difference is observed. Toxicity is more obvious in males than females. The mechanisms underlying its potential toxicity may be the imbalance in the glutathione antioxidant system, the induction of excessive oxidation, the triggering of inflammatory reaction, the activation of the expression of caspase-3, and the induction of cell apoptosis.

\section{Cytokine Pathway}

Aristolochic acid can cause renal interstitial fibrosis. The occurrence of renal interstitial fibrosis is related to the increase of extracellular matrix (ECM) synthesis and the decrease of ECM degradation. TGF- $\beta$ is one of the important cytokines that promote ECM synthesis (Sun et al., 2018). The expression of TGF- $\beta$, CTGF, and ECM increase considerably in kidney tissues of patients (Zhang et al., 2005; Bai et al., 2014; Tsai et al., 2014). Exogenous aristolochic acid I could increase the mRNA expression of TGF- $\beta$ and ECM in renal tubular epithelial cells and renal interstitial fibroblasts (Zhu et al., 2007; Tian et al., 2014; Lu et al., 2016; Li M. et al., 2018). The specific anti-TGF- $\beta 1$ neutralizing antibody could partially block the expression of FN and HK-2 cell apoptosis induced by aristolochic acid I (Li et al., 2004). The abnormal expression of FN could promote cell proliferation, leading to renal interstitial fibrosis (Nortier et al., 2015; Chen et al., 2018; Li M. et al., 2018; Yin et al., 2018). TGF- $\beta 1$ partially mediates the occurrence of FN and the apoptosis of renal tubular epithelial cells induced by aristolochic acid I.

\section{Influence on Cell Transdifferentiation}

Chronic AAN (CAAN) and renal interstitial fibrosis can occur in patients treated for a long time with low-dose aristolochic acid (He et al., 2008). VIM is expressed in the renal tubular epithelial cells of patients with CAAN, whereas the expression of CK decreases (Chai et al., 2009; Yi et al., 2018). This finding indicates that renal tubular epithelial cells undergo phenotypic transformation during the course of the disease and are converted into myofibroblasts.

\section{Mechanism Related to Ischemic Changes}

The kidney tissues of 33 patients treated with aristolochic acid showed renal ischemia, glomerular collapse and shrinkage, thickening of the capsular sac wall, and thickening of the interlobe arteries and arterioles (Depierreux et al., 1994). Many patients taking Akebia quinata (Thunb.) Decne. have renal ischemic changes in the pathological area (Shi et al., 2016; Wang et al., 2018). Hence, aristolochic acid may cause renal damage through vascular damage, the specific manifestation of which is the damage to the tubular wall of the kidney, thereby causing ischemia and eventually leading to renal tubular atrophy and interstitial fibrosis. After administration of $10 \mathrm{~g} / \mathrm{kg}$ of $A$. obliqua S. M. Hwang to rats in the experimental group for 4 weeks, 6-keto-PGF1 $\alpha$ and TXB2 in urine, plasma, and kidney tissue decreased remarkably (Ye et al., 2003). Both are metabolites of PGI2/TXA2. PGI2/TXA2 is among the key factors that determine renal blood flow and function. However, because of the instability of its molecular structure, the content of PGI2/TXA2 can be determined by detecting the content of 6keto-PGF1 $\alpha$ and TXB2. Hence, the changes in the contents of the two compounds can reflect the vascular constriction caused by the abnormal prostaglandin system, which is one of the mechanisms underlying renal injury.

\section{Immune-Mediated Pathway}

Continuous administration of esculentoside A for 7 days causes renal injury. In this case, $\mathrm{p}-\mathrm{I} \kappa \mathrm{B} \alpha$ protein expression increases significantly, whereas $\mathrm{I} \kappa \mathrm{B} \alpha$ protein expression decreases obviously. TNF- $\alpha$ and IL-1 $\beta$ expression are remarkably upregulated. Hence, the nephrotoxicity induced by esculentoside $A$ in rats is very closely related to NF- $\kappa \mathrm{B}$. The potential nephrotoxic mechanism of esculentoside A may be the activation of the NF- $\kappa \mathrm{B}$ signal, phosphorylation of the target protein of $\mathrm{I} \kappa \mathrm{B} \alpha$, and the overexpression of the downstream inflammatory factors TNF- $\alpha$ and IL-1 $\beta$ to induce renal damage (Yang X. et al., 2019).

\section{Acute Toxicity \\ Mechanism Related to Apoptosis}

Aristolochic acid induces cell apoptosis and causes direct damage to renal tubular epithelial cells, especially the proximal tubular epithelial cells (Yang H. Y. et al., 2011). Its mechanism may be related to the increase of intracellular calcium concentration (Hsin et al., 2006). By using aristolochic acid I to induce LLCPK1 cell apoptosis model and by applying calcium antagonist (lacidepine) to reverse this effect, the calcium ion concentration caused by aristolochic acid I in the cell decreases, and the number of apoptotic cells is substantially reduced. Aristolochic acid I may cause cell apoptosis by regulating intracellular calcium concentration (Gao et al., 2000; Ma et al., 2015). In addition, the aristolochic acid metabolite, aristolochia lactam, is possibly one of the toxic components. The microscopic images of aristolochia lactam-treated HK-2 cells show typical apoptosis characteristics, in which the cell body shrinks, turns around, and even falls off (Wen et al., 2006; Jing et al., 2017).

\section{Mechanism of Oxidative Damage}

T. regelii Sprague. et Takeda. poisoning often leads to acute kidney injury and renal failure. ROS plays an important role in acute renal failure (Matsushita et al., 2011; Stratta et al., 2012; Ghosh et al., 2013; Xi et al., 2017; Hajihashemi et al., 2018). When the body's oxidation and antioxidant functions are disordered, and a large number of oxygen free radicals cannot be promptly removed, this results in the occurrence of lipid peroxidation damage, which may be one of the nephrotoxic mechanisms of $T$. regelii Sprague. et Takeda (Huang et al., 2019). Triptolide, the main toxic components of T. regelii Sprague. et Takeda, can considerably inhibit the activities of SOD and GSH-Px and remarkably increase the expression of ROS and MDA in rat kidney. These changes are positively correlated with dose. Moreover, the expressions of ROS and MDA is closely related to the degree of renal injury (Yang F. et al., 2011). This finding shows that triptolide can inhibit the activity of antioxidant enzymes in the renal tissue of rats, thereby breaking the balance of oxidation 
and antioxidation. ROS becomes difficult to remove from renal tissues, resulting in the accumulation of ROS, which in turn leads to severe lipid peroxidation and serious kidney damage.

\section{Cell Transporter Inhibition}

The main nephrotoxic component of Gardenia jasminoides Ellis is gardenoside. The renal toxicity of gardenoside is related to the inhibition of tubule transporters (Feng et al., 2016). Geniposide can remarkably inhibit the expression of Oat1 and Oat 3 in the kidney at high doses $\left(300 \mathrm{mg} \cdot \mathrm{kg}^{-1}\right)$ for a short period (Feng, 2016). Oat1 and Oat3 are the main organic anion transporters that mediate the toxic substance excretion of the kidney (Nigam et al., 2015; Wen et al., 2018); their expressions are distributed in the rat kidney, especially in the renal tubules and suprarenal glands. The decrease in the expression of Oat1 and Oat 3 may cause inflammation in the kidney (Masereeuw and Russel, 2010), thereby reducing the excretion of renal toxic substances and increasing the accumulation of organic anions, and leading to kidney damage.

\section{DNA Damage Mechanism}

The metabolites of aristolochic acid in vivo, namely, aristolochic acid I and aristolochic acid II, can covalently bind with deoxyadenine and deoxyguanine in DNA to produce DNA adducts (Jelaković et al., 2019; Yang H. Y. et al., 2019), thereby damaging the DNA structure, affecting DNA biochemical function, and causing mutations in the P53 gene (Slade et al., 2009; Zhang et al., 2015; Sborchia et al., 2019). This adduct was first detected in the kidney of patients with CHN (Arlt et al., 2001; Stiborová et al., 2001). A certain dose of aristolochic acid I can cause DNA damage to renal tubular epithelial cells, leading to a comet tail phenomenon. Moreover, aristolochic acid I can cause cell cycle arrest in the G2/M phase (Li et al., 2006). Hence, aristolochic acid can be toxic to the kidney through the DNA damage pathway (Li et al., 2010). Table 3 and Table 4 summarizes some mechanisms of kidney injury. Figure $\mathbf{2}$ gives a detailed description of some kidney injury mechanisms.

\section{CAUSES OF NEPHROTOXICITY}

More than 100 kinds of HM preparations that cause kidney damage are recorded in the Pharmacopoeia of the People's Republic of China. These HM drugs are represented by Aristolochia obliqua S.
M. Hwang, Caulis Aristolochiae manshuriensis, Radix Euphorbiae pekinensis, cinnabar, and Fructus Meliae toosendan. The causes of their nephrotoxicity are diverse. The use of drugs with strong renal toxicity in clinical practice should be avoided as much as possible. If the use of such drugs is unavoidable, substituting other drugs with the same efficacy or processing the drugs should be considered. Toxicity must be reduced or eliminated through reasonable processing and compatibility.

\section{Environmental Factors}

The cultivation and growth of HM plants are inevitably affected by their surrounding environment. Large differences may exist in the compositions of the same kind of medicinal materials from different places of origin. Patients often opt to increase dosages for treatment when the content of effective ingredients is low. In this case, the toxic components ingested by patients also increase, thus resulting in kidney damage. When the soil, air, and water of the habitat of the HM plants are polluted, adverse phenomena, such as heavy metal concentrations exceeding standards, may occur (Gao and Shi, 2020).

\section{Misuse of HM}

Homonyms and synonyms are common in HM but may represent drugs from completely different plants and with greatly different compositions. These drugs are often misused given their identical or similar names. In Belgium, cases of kidney damage caused by taking HM for weight loss (Vanherweghem et al., 1993) are due to the use of A. obliqua S. M. Hwang as Stephaniae tetrandra Radix. Although the names of the two drugs are similar, the drugs themselves are different. A. obliqua S. M. Hwang has a high content of aristolochic acid, which can cause a series of diseases, such as the apoptosis or necrosis of renal tubular epithelial cells and renal ischemia (Zhang et al., 2019).

\section{Excessive Dosage}

Ancient and modern Chinese medicine practitioners have developed a series of symptomatic prescriptions during practice over the thousand years of HM use. In clinical application, prescriptions are often adjusted to increase their applicability in accordance with the needs of the disease and the differentiation and treatment of syndromes. Excessively high dosages result in the accumulation of toxic components in the body because of untimely metabolism; this effect will cause kidney damage in the long run (Wang and Liu, 2009).

TABLE 3 | Nephrotoxic Mechanism of Single Component.

\begin{tabular}{|c|c|c|c|}
\hline Component & Experimental cell/animal & Path & References \\
\hline emodin & $\mathrm{HK}-2$ & $\begin{array}{l}\text { MAPK/ERK Signal transduction } \\
\text { pathway }\end{array}$ & (Wang et al., 2010) \\
\hline rhein & Rat & Glutathione antioxidant system & (Hu et al., 2019) \\
\hline Aristolochic acid & $\mathrm{HK}-2$ & $\begin{array}{l}\text { TGF- } \beta / \text { Smad independent signaling } \\
\text { pathways ( } \beta \text {-catenin, Ras-Raf-Erk1/2 } \\
\text { signaling pathways) }\end{array}$ & (Li J. et al., 2018) \\
\hline Aristolochic acid & $\mathrm{HK}-2$ & 6-keto-PGF1 $\alpha$ and TXB 2 & (Ye et al., 2003) \\
\hline Aristolochic acid & LLC-PK1 & intracellular calcium concentration & (Gao et al., 2000) \\
\hline Aristolochic acid & Rat & P38 MAKP signaling pathway & (Zhang et al., 2015) \\
\hline Esculentoside A & Rat & $N F-\kappa B$ signaling pathway & (Yang X. et al., 2019) \\
\hline
\end{tabular}


TABLE 4 | Nephrotoxic Mechanism of HM.

\begin{tabular}{|c|c|c|c|}
\hline HM & Experimental animal & Path & References \\
\hline Cinnabaris & Rat & $\begin{array}{l}\text { Death receptor mediated apoptosis signaling } \\
\text { pathway }\end{array}$ & (Wang et al., 2015a) \\
\hline Cinnabaris & Rat & $\begin{array}{l}\text { Mitochondrial mediated endogenous } \\
\text { pathway }\end{array}$ & (Gao et al., 2009) \\
\hline $\begin{array}{l}\text { Leonurus ja ponicus } \\
\text { Houtt. }\end{array}$ & Rat & the purine metabolism & (Huang and Sun, 2010) \\
\hline $\begin{array}{l}\text { Tripterygium regelii } \\
\text { Sprague. et Takeda. }\end{array}$ & Rat & the purine metabolism & (Huang et al., 2019) \\
\hline $\begin{array}{l}\text { Gardenia jasminoides } \\
\text { Ellis. }\end{array}$ & Rat & Oat1, Oat3 & (Masereeuw and Russel, 2010) \\
\hline
\end{tabular}

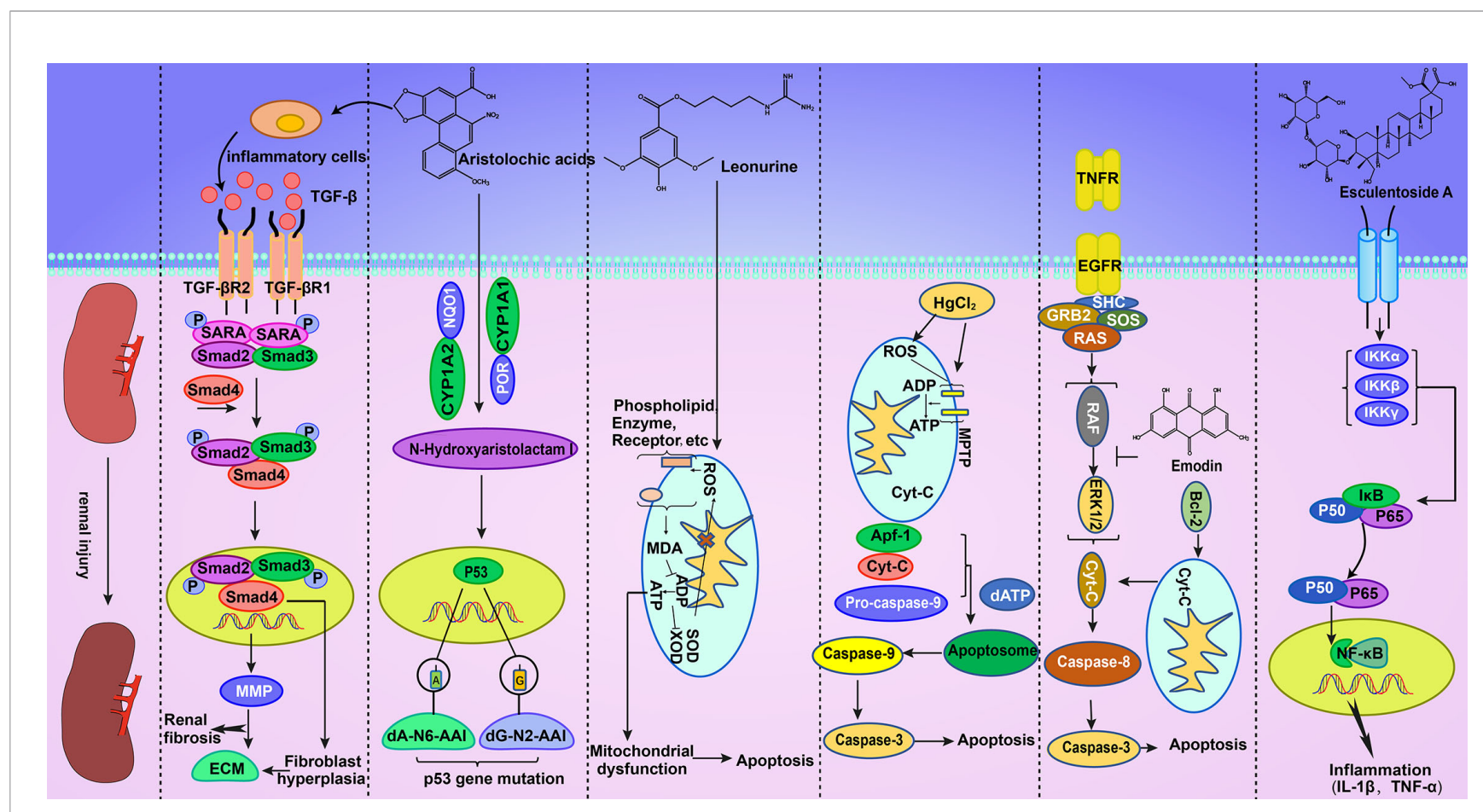

FIGURE 2 | AAI can activate TGF- $\beta /$ Smad-independent signaling pathways to cause abnormal cell proliferation. This effect results in the production of a large amount of ECM, which can aggravate the degree of renal fibrosis. In addition, AAl can cause P53 gene mutations in the nucleus. Geniposide can increase ROS in vivo, thereby damaging oxidative phosphorylation and subsequently leading to apoptosis. Mercury can combine with biological macromolecules on the cell membrane, improve mitochondrial permeability, release Cyt-c, enhance oxidation, and cause apoptosis. Emodin can inhibit the phosphorylation of ERK1/2, thus triggering apoptosis. Esculentoside A can cause cell inflammation through the NF-кB signaling pathway.

\section{Lack of the Understanding of HM}

Given the lack of the understanding of HM, users may be confused by folk traveling doctors and refer to folk prescriptions, thus resulting in the misuse or abuse of HM and ultimately in kidney damage.

\section{Improper Processing or Boiling}

Processing has played an important role in the history of $\mathrm{HM}$ as a major measure for reducing the toxicity and increasing the efficiency of $\mathrm{HM}$ drugs. If drugs are properly processed, the toxicity of HM drugs can be greatly reduced or even eliminated, and at the same time, efficacy may be increased (Zhang et al., 2020). In addition, the selection of processing utensils, time, and temperature for the boiling process is crucial. For example, casseroles, rather than iron, aluminum, and other metal utensils, are often selected for processing and boiling HM preparations.

\section{Improper Compatibility}

Compatibility is also a vital measure for reducing toxicity and increasing the efficiency of HM. HM drugs should not only be compatible with each other but also with Western medicine. However, inappropriate compatibility can lead to injury. For example, when Shuanghuanglian injection is used in combination with glucose, insoluble particles are produced, thus affecting metabolism and causing kidney damage (Zhang et al., 2013). Radix Aconiti Kusnezoffii in combination with Radix Trichosanthis and Bulbus Fritillariae thunbergii cause a series of adverse reactions (Li, 2016; Li et al., 2016). 


\section{Special Constitution}

A small number of patients with allergic constitution and special genetic diseases may not tolerate certain drugs. Intolerance results in kidney damage.

\section{Improper Use}

Although some drugs are toxic, adverse reactions can be avoided when they are used correctly in the clinic. For example, most mineral drugs often lead to kidney damage when used internally but can exert a bacteriostatic and bactericidal effect when used externally (Bai et al., 2011; Ding, 2012; Liu, 2020).

\section{CLINICAL APPLICATION}

\section{HM Containing Aristolochic Acid}

Acute renal failure Yin Guang analyzed 31 cases of patients with AAN and found eight cases of patients with acute renal failure (ARF) caused by taking large doses of Caulis A. manshuriensis decoction (dose $>10 \mathrm{~g} /$ day). The cases exhibited renal injury accompanied by gastrointestinal or liver injury and high levels of small-molecular proteins in urine (Yin et al., 2010). In addition, 58 cases of patients with AAN were examined via renal puncture. Light microscopy showed that in the patients, renal tubular epithelial cells were severely denatured, necrotic, and disintegrated, and a small amount of lymphoid and mononuclear cells were sporadically infiltrated. The results of electron microscopy revealed that the surfaces of tubular epithelial cells had lost microvilli. Moreover, mitochondrial swelling was found in renal tubular epithelial cells. In addition to secondary lysosome formation, organelle disintegration and renal interstitial edema were discovered. Furthermore, the foot process of glomerular visceral epithelial cells exhibited mild segmental fusion, and the mesangial matrix increased slightly; however; electronic compacts were not observed (Chen et al., 2001).

Chronic renal failure Longdan Xiegan pill has the effects of relieving the dampness and heat of liver and gallbladder, as well as dizziness, tinnitus, and deafness. One of its prescriptions is Caulis A. manshuriensis, which contains a large amount of aristolochic acid that causes renal damage. A total of 21 cases of patients with chronic renal failure caused by taking Longdan Xiegan pills were analyzed. Most of the patients took the medicine for more than 1 year or even for more than 10 years (Li S. H. et al., 2018). In patients with chronic renal failure, light microscopy showed that the renal interstitium appeared multifocal or exhibited massive fibrosis, renal tubules showed multiple or large areas of atrophy, and some glomeruli presented ischemic basement membrane shrinkage and sclerosis. Electron microscopy results revealed a large number of fascicular collagen fibers in the renal interstitium, and the basement membrane of renal tubules and glomeruli had thickened and shrunk (Chen et al., 2001).

\section{Tripterygium regelii Sprague. et Takeda.}

In the treatment of glomerular diseases, T. regelii Sprague. et Takeda. can eliminate urinary protein. Although its curative effect is exact, its toxic and side effects are severe. Six patients with nephrotic syndrome due to taking $T$. regelii Sprague. et Takeda. were observed. Among them, four developed ARF within 21-120 days after taking $T$. regelii Sprague. et Takeda. Liver and kidney functions were slightly damaged in two cases, and blood cell counts (red blood cells, white blood cells, and platelets) decreased and menstrual disorders were observed. Renal biopsy indicated severe renal interstitial and tubular lesions. Under light microscopy, obvious inflammatory cell infiltration was found in tubules and interstitium, and the obvious degeneration, necrosis, and atrophy of tubular epithelium cells were observed (Wang et al., 1996). The causes of death of 83 patients who died from taking T. regelii Sprague. et Takeda. were analyzed. Among them, 65 cases were due to ARF or circulatory failure (Wang et al., 1999).

\section{Leonurus ja ponicus Houtt.}

Leonurus ja ponicus Houtt. was first published in Shennong's Classic Materia Medica. It is considered to be a safe and nontoxic HM drug that is widely used in the clinic. It has the functions of activating blood and regulating menstruation, disinhibiting urine, dispersing swelling, clearing heat, and removing toxins. A poisoning death caused by Leonurus ja ponicus Houtt. was reported in the late 1980s. The patient took a $400 \mathrm{~g}$ decoction of Leonurus ja ponicus Houtt. and died of abdominal pain, headache, lower back pain, and multiple organ bleeding 1 day later. Analytical results showed that the excessive dosage and repeated use of Leonurus ja ponicus Houtt. resulted in renal failure and death by poisoning (Luo et al., 2018c).

\section{Fructus Xanthii}

Fructus Xanthii is the fruit of Xanthium Caulis et Folium, which is mainly used to treat wind cold headache. A patient experienced acute liver and kidney damage and coagulation dysfunction by ingesting a large number of unprocessed Fructus Xanthii. Light microscopy showed that the patient's renal tubulointerstitial lesions were severe. Moreover, in the patient, the tubular structure was clear, and diffuse renal tubular epithelial cells were swollen and degenerative. The patient exhibited occasional renal tubular atrophy and renal interstitial fibrosis with a small amount of inflammatory cell infiltration, and also presented a small number of eosinophils (Wang et al., 2013). Another patient experienced upper abdominal discomfort, nausea, vomiting, diarrhea, and reduced urine production accompanied by facial and lower limb edema; the patient was clinically diagnosed with acute renal failure and toxic hepatitis (Sun and Hei, 1997).

\section{Cinnabar}

Cinnabar has the effect of tranquilizing the mind. It is mainly used in the treatment of palpitations, insomnia, and seizures. A man developed abdominal pain, nausea, and vomiting after taking cinnabar ( $4.5 \mathrm{~g} /$ day) for 1 month to treat palpitations and insomnia in accordance with a folk prescription. After he continued taking cinnabar for 1 month, he developed general weakness, lower-limb edema, proteinuria, and oliguria and gradually stopped producing urine. His blood urea, urea 
nitrogen, nonprotein nitrogen, and creatinine levels increased significantly. In addition, his liver function transaminase and blood potassium levels increased, whereas his blood chlorine and blood glucose levels decreased. He was diagnosed with mercury poisoning and acute renal failure (Guo and $\mathrm{Li}, 2001$ ). One woman took more than $100 \mathrm{~g}$ of cinnabar within 30 days to treat palpitations. She developed nausea, vomiting, severe abdominal pain, and diarrhea. Her stool was brown likely because of the corrosion of gastrointestinal mucosa. On the first day after her gastrointestinal symptoms appeared, she exhibited oliguria; on the second day, she did not produce urine and her BUN was $50.5 \mathrm{mg} \%$. She was diagnosed with acute renal failure (Zhang and Wang, 1985).

\section{PREVENTION STRATEGIES}

Although many HMs have nephrotoxicity and their ingredients and mechanisms are quite complex, some necessary prevention measures should be employed to reduce or even avoid renal damage.

Knowledge about HM should be further disseminated, and the indications of HM should be strictly controlled. In the process of using traditional Chinese medicine, people should focus on the source of HM, processing methods, and standardized methods of use. To prevent the occurrence of drug allergy, the doctor should ask for the details on the patient's history of drug use and allergies. The drug that once caused allergy should not be reused. Dosage and duration of medication need to be controlled within a reasonable range; this approach can prevent the accumulation of drugs in the body, which results in toxicity.

Considering that the toxic components of some HMs are also their effective ingredients, besides the abovementioned general prevention and control measures, the most effective attenuating measures for HM involve processing and compatibility.

Processing refers to the baking, cooking, frying, washing, soaking, bleaching, steaming, and boiling of Chinese HMs. Through these methods, the efficacy of HMs is enhanced, and their side effects are reduced. Moreover, the performance and efficacy of HMs are changed. Simple processing can facilitate the storage and transportation of most Chinese medicines. The processing of HMs dates back thousands of years in the past. In the "Prescriptions for Fifty-two Diseases," several methods of processing HM are recorded for the first time. Several books on Chinese medicine, such as "Inner Canon of Huangdi," "Sheng Nong's herbal classic," "Treatise on Cold Pathogenic Diseases," and "Synopsis of Golden Chamber," discuss the processing of HMs and have hundreds of processing methods. Processing is an effective and reliable measure for reducing toxicity and increasing efficiency, according to Chinese medicine history.

The nephrotoxicity of HMs is a serious toxic side effect of HMs. This area has been explored since its discovery. Statistics show that in the national standard, approximately 801 compound Chinese patent medicines contain rhubarb. Its application range includes multiple medical fields. It is used for detoxification, lipid lowering, and weight loss. Considering its good taste, rhubarb is used as a flavoring ingredient in Western desserts. According to the "Pharmacopoeia of the People's Republic of China," more than 20 kinds of processed products have been made from rhubarb. Raw, cooked, and alcohol-processed rhubarb and rhubarb charcoal are the most commonly used rhubarb artillery products in modern clinical practice. The anthraquinone component in rhubarb is its effective component, but it causes hepatotoxicity and nephrotoxicity. After processing, the effective ingredients of rhubarb change. In comparison with processed rhubarb, raw rhubarb has stronger heat clearing and detoxifying effects ( $\mathrm{Fu}$ et al., 2014). Processing greatly reduces the anthraquinone components. After processing by wine, vinegar, and other methods, the glycosidic bond in the anthraquinone component of rhubarb is broken at high temperature, resulting in a large amount of free anthraquinone (especially physcion and chrysophanol) (Zhu et al., 2016). Subsequently, the toxicity of rhubarb, the effect of purgation, and the stimulatory effect on the gastrointestinal tract are substantially reduced.

Aconitum is associated with heart, nerve, and digestive system toxicity, but it has good anti-inflammatory, analgesic, immunosuppressive, anti-tumor, and cardiotonic effects. It can also lower blood pressure and dilate blood vessels and can be used to treat chronic rheumatism heart failure and chronic renal failure (Wei et al., 2019). Therefore, a high-temperature decoction is often combined with physical soaking to accelerate the decomposition of toxic alkaloids in aconitum, to maximize the drug's clinical effect (Singhuber et al., 2009). Magnoliae Officinalis Cortex is generally clinically processed into ginger juice Magnoliae Officinalis Cortex by different methods. The contents of alkaloids and some glycosides decreased significantly after the processing of Magnoliae Officinalis Cortex; moreover, the toxicity is reduced (Yu et al., 2010). Many HMs, such as Melia toosendan, motherwort, and cinnamon, are used after going through various processing methods for the achievement of attenuation and synergistic effects.

Compatibility refers to the combined application of drugs to produce a certain synergistic or detoxifying effect. Chinese medicine is divided into seven kinds of laws in clinical application. In addition to the use of a single drug to treat a disease with a single condition, the six other rules refer to the description of drug compatibility. A combination of two drugs with similar efficacy can enhance the efficacy of the original drug. One medicine is the main drug, whereas the other is the auxiliary drug. When used together, the auxiliary drug can improve the efficacy of the main drug. The side effects of one drug can be inhibited by the other. One drug can eliminate the side effects or destroy the efficacy of the other drug. The use of two drugs together can also induce severe toxic side effects.

For example, T. wilfordii Hook F. has anti-inflammatory, analgesic, anti-tumor, and immunomodulatory effects. It is used in the treatment of immune, renal, and skin diseases; it is especially used for rheumatoid arthritis (Song et al., 2020). However, considering its severe toxic side effects, especially on the liver and kidney, the clinical application of T. wilfordii Hook F. has been limited (Li et al., 2014; Qu et al., 2015; Xi et al., 2017; Zhou et al., 
2017). Many studies have been conducted to reduce its toxicity and expand its clinical applications. To achieve detoxification by compatibility, various detoxification measures can be employed. One method is the combination with a single medicine to reduce toxicity. After exploring the usage rules of T. wilfordii Hook F., various single medicines that are compatible with T. wilfordii Hook F. were found, including Radix Astragali, Salvia miltiorrhiza, Radix Paeoniae Alba, licorice, Szechuan lovage rhizome, and Radix Rehmanniae. The compatibility of $T$. wilfordii with licorice and Radix Astragali can reduce its nephrotoxicity. Second, combination with compound drugs can reduce $T$. wilfordii's toxicity. In clinical practice, compound compatibility has been used to reduce the toxicity of $T$. wilfordii Hook F. to ensure its clinical application. Many compound medicines can effectively reduce the toxicity of $T$. wilfordii Hook F. and expand its clinical applications, such as Xinfeng Capsule, External Applied Compound T. wilfordii Hook F. and others. Xinfeng Capsule is compounded with Radix Astragali, Coix Seed, T. wilfordii Hook F., and Centipede. Xinfeng Capsule can treat arthrosis in patients with rheumatic diseases and comprehensively improve the extra-articular disease and quality of life of patients. No obvious side effects and functional damage of liver and kidney are found during the treatment. With the development of modern western medicine and technology, HMs have gradually become modernized. In terms of compatibility and toxicity reduction, new types of attenuation methods to reduce toxicity have been developed, such as combining with western medicine and studying the compatibility of ingredients. For the treatment of rheumatoid arthritis, some of the western medicines compatible with T. wilfordii Hook F. are methotrexate, leflunomide, and etanercept (He et al., 2014; Zhou et al., 2018). In addition, the combination of tripterysium glycoside tablets with calcium dobesilate dispersible tablets or methylprednisolone is used clinically to treat nephrotic syndrome, and adverse reactions caused by this treatment are relatively slight (Shang et al., 2018). Traditional single drug compatibility and compound drug compatibility have the disadvantages of complex ingredients, low effective content, and uncontrollable quality. Therefore, some scholars have proposed a new way to reduce toxicity, which is to study the compatibility of ingredients. The combination of total glucosides of paeony and tripterygium glycoside has increased efficiency and low toxicity in the treatment of lupus nephritis ( $\mathrm{Li}$ et al., 2009). The combination of tripterygium glycoside and artesunate can effectively be used to treat adjuvant arthritis in rats. Diammonium glycyrrhizinate can significantly reduce the cytotoxic effect induced by T. wilfordii Hook F. on MDCK cells, effectively antagonize chromosomal damage, and reduce gastrointestinal reactions.

The toxicity of $M$. toosendan to the liver, kidney, and hematopoietic system of rats showed significant time-effect and dose-effect relationships (Xiang et al., 2012). Moreover, it can be used in the treatment of abdominal distention and pain. Hence, M. toosendan is often used in combination with Radix Paeoniae Alba to reduce liver inflammatory response. Fructus Xanthii is used in the clinical treatment of nasopharyngeal carcinoma and the pain and paralysis of joint tissue caused by rheumatism. The toxic proteins contained in Fructus Xanthii can cause damage to the parenchymal organs, especially to the liver (Wang et al., 2011). Therefore, Fructus Xanthii is often used in combination with Radix astragali to reduce its damage to the liver.

In conclusion, processing and compatibility play a large role in reducing the toxicity and increasing the efficiency of HM. Therefore, when inheriting the tradition, people should use new technology to explore new methods of reducing toxicity and increasing the efficiency of HM to improve the clinical application of HM.

\section{CONCLUSIONS AND FUTURE PERSPECTIVES}

In this review, the nephrotoxic components in HM and their mechanism of toxicity were introduced in detail. On this basis, various causes of nephrotoxicity were proposed. The traditional measures of reducing toxicity and increasing efficiency should be used in accordance with modern research to achieve treatment.

HM was once considered as natural, nontoxic, and green. However, a large number of clinical reactions show that HM drugs contain many unknown ingredients, some of which are toxic, whereas some components may react in the human body to produce toxic substances. These situations suggest that research on the toxicity of HM should be strengthened. In addition, the metabolic process of each component in the body should be studied to prevent the accumulation of toxic drugs. In this regard, metabolomics and other technologies can be used to study and speculate the in vivo processes and toxicity mechanism of each component to improve studies on the prevention and control measures of HM components.

In this review, the nephrotoxicity of HM drugs was summarized in detail to ensure their safe application in clinical practice. At the same time, quality control standards for HM should be established worldwide to promote the development of the Chinese medicine industry.

\section{AUTHOR CONTRIBUTIONS}

XX: Conceptualization, Formal analysis, Investigation, Writingoriginal draft. RZ, JY, and MZ: Conceptualization, Formal analysis, Investigation. XW: Formal analysis, Investigation. KW and GC: Funding acquisition, Project administration, Validation, Writing-review. All authors contributed to the article and approved the submitted version.

\section{FUNDING}

This work was financially supported by the National Natural Science Foundation of China (No.81922073), the Traditional Chinese Medicine Key Scientific Research Fund Project of Zhejiang Province (No.2018ZY004), and Natural Science Foundation Exploration project of Zhejiang Province (LQ20H280003). 


\section{REFERENCES}

Arlt, V. M., Pfohl-Leszkowicz, A., Cosyns, J., and Schmeiser, H. H. (2001). Analyses of DNA adducts formed by ochratoxin A and aristolochic acid in patients with Chinese herbs nephropathy. Mutat. Res. 494, 143-150. doi: 10.1016/s1383-5718(01)00188-7

Avci Çiçek, E., Rota, S., Dursun, B., and Kavalci, E. (2016). Evaluation of serum NGAL and hepcidin levels in chronic kidney disease patients. Ren. Fail. 38, 3539. doi: 10.3109/0886022X.2015.1107823

Bai, M., Jia, Y. Q., Yang, K. W., Feng, L., and Miao, M. S. (2011). Examples and pharmacological effects of realgar for external use. China Mod. Med. 18, 8-9.

Bai, Y. H., Lu, H., Hu, L. P., Hong, D., Ding, L., and Chen, B. (2014). Effect of Sedum sarmentosum BUNGE extract on aristolochic acid-induced renal tubular epithelial cell injury. J. Pharmacol. Sci. 124, 445-456. doi: 10.1254/ jphs.13216fp

Betton, G. R., Ennulat, D., Hoffman, D., Gautier, J. C., Harpur, E., and Pettit, S. (2012). Biomarkers of collecting duct injury in Han-Wistar and SpragueDawley rats treated with N-phenylanthranilic Acid. Toxicol. Pathol. 40, 682694. doi: $10.1177 / 0192623311436174$

Bihorac, A., Chawla, L. S., Shaw, A. D., Al-Khafaji, A., Davison, D. L., Demuth, G. E., et al. (2014). Validation of cell-cycle arrest biomarkers for acute kidney injury using clinical adjudication. Am. J. Respir. Crit. Care Med. 189, 932-939. doi: 10.1164/rccm.201401-0077OC

Chai, J. J., Chen, Y. P., and Rui, H. L. (2009). Effects of Hirsutella sinensis on TGFbeta1 and Snail expressions and transdifferentiation of tubular epithelialmyofibroblast in renal tissue of rats with chronic aristolochic acid nephropathy. Chin. J. Integr. Tradit. Western Med. 29, 325-329.

Chen, W., Zhan, Y. P., Li, A., Chen, H., Dong, B., Zou, W. Z., et al. (2001). The clinical and pathological manifestations of aristolochic acid nephropathy-the report of 58 cases. Natl. Med. J. China. 81, 16-20.

Chen, W., Zhang, L., Zhou, Z. Q., Ren, Y. Q., Sun, L. N., Man, Y. L., et al. (2018). Effects of Long Non-Coding RNA LINC00963 on Renal Interstitial Fibrosis and Oxidative Stress of Rats with Chronic Renal Failure via the Foxo Signaling Pathway. Cell. Physiol. Biochem. 46, 815-828. doi: 10.1159/000488739

de Geus, H. R., Betjes, M. G., and Bakker, J. (2012). Biomarkers for the prediction of acute kidney injury: a narrative review on current status and future challenges. Clin. Kidney J. 5, 102-108. doi: 10.1093/ckj/sfs008

Deng, N., Yi, Y., Liang, A. H., Li, C. Y., Zhao, Y., Pan, C., et al. (2018). Mechanism of Nephrotoxicity of Rhubarb in Rats. China J. Chin. Mater. Med. 43, 27772783. doi: 10.19540/j.cnki.cjcmm.20180314.001

Ding, X. K. (2012). New congnition of antiviral pharmacological action in cinnabar and realgar. J. Clin. Ration. Drug Use 5, 8-9. doi: 10.15887/ j.cnki.13-1389/r.2012.19.021

Depierreux, M., Van Damme, B., and Vanden Houte, K. (1994). Pathologic aspects of a newly described nephropathy related to the prolonged use of Chinese herbs. Am J Kidney Dis. 24, 172-180. doi: 10.1016/s0272-6386(12)80178-8

Feng, X. Y., Tian, J. Z., Yi, Y., Li, C. Y., Zhang, Y. S., Wang, L. M., et al. (2016). Nephrotoxicity Effect of Gardenoside in Rats. Chin. J. Exp. Tradit. Med. Formulae. 22, 118-121. doi: 10.13422/j.cnki.syfjx.2016100118

Feng, X. Y. (2016). The Study of Nephrotoxicity and Primary Mechanism Induced By the Gardenia and Its Main Component Geniposide. Capital Med. Univer. 1-96.

Fernández, J., Clària, J., Amorós, A., Aguilar, F., Castro, M., Casulleras, M., et al. (2019). Effects of Albumin Treatment on Systemic and Portal Hemodynamics and Systemic Inflammation in Patients With Decompensated Cirrhosis. Gastroenterology 157, 149-162. doi: 10.1053/j.gastro.2019.03.021

Fu, S. Z., Wang, T. T., Gao, W. Y., and Li, X. (2014). Comparision of contents of anthraquinones and phenolic acids compounds in different processed products from Rheum officinale by principal component analysis. Pubmed 39, 833-837. doi: $10.4268 / \mathrm{cjcmm} 20140515$

Gao, G., and Shi, X. G. (2020). Main factors affecting the quality and clinical efficacy of Chinese herbal pieces and Countermeasures. Chin. J. Modern Drug Appl. 14, 214-216. doi: 10.14164/j.cnki.cn11-5581/r.2020.11.100

Gao, R. T., Zheng, F. L., Liu, Y., Zheng, D., Li, X., Bo, Y., et al. (2000). Aristolochic acid I-induced apoptosis in LLC-PK1 cells and amelioration of the apoptotic damage by calcium antagonist. Chin. Med. J. (Engl.) 113, 418-424.

Gao, J., Xu, Z. F., Deng, Y., Xu, B., Guan, K., and Xin, X. (2009). Effects of mercury on ATPase and mitochondrial membrane potential in rat renal cortex. China. Occup. Med. 36, 461-463.
Ghosh, P., Roy, S. S., Chakraborty, P., Ghosh, S., and Bhattacharya, S. (2013). Effects of organoselenium compound 2-(5-selenocyanato-pentyl)-benzo[de] isoquinoline 1,3-dione on cisplatin induced nephrotoxicity and genotoxicity: an investigation of the influence of the compound on oxidative stress and antioxidant enzyme system. BioMetals 26, 61-73. doi: 10.1007/s10534-0129594-y

Gocze, I., Koch, M., Renner, P., Zeman, F., Graf, B. M., Dahlke, M. H., et al. (2015). Urinary biomarkers TIMP-2 and IGFBP7 early predict acute kidney injury after major surgery. PLoS One 10, e0120863. doi: 10.1371/journal.pone. 0120863

Guo, X. L., and Li, J. F. (2001). A case of chronic renal failure caused by taking cinnabar. Pract. Pharm. Clin. Rem. 4, 139. doi: 10.14053/j.cnki.ppcr.2001. 03.039

Hajihashemi, S., Jafarian, T., Ahmadi, M., Rahbari, A., and Ghanbari, F. (2018). Ameliorative Effects of Zataria Multiflora Hydro-Alcoholic extract on Gentamicin Induced Nephrotoxicity in Rats. Drug Res. (Stuttg). 68, 387-394. doi: $10.1055 / \mathrm{s}-0043-124968$

He, C. M., Zheng, F. L., and Liu, Y. P. (2008). The effects of mycophenolate mofetil on renal Interstitial fibrosis and epithelial-myofibroblast translation in adenine-induced renal failure rats. Chin. J. Intern. Med. 47, 901-905.

He, W. Z., Yin, Z. H., Gao, J. H., Ye, Z. Z., Xie, Y., Kong, W. H., et al. (2014). Etanercept combined with Tripterygium wilfordii polyglycoside for treatment of rheumatoid arthritis in the elderly: a clinical study. Zhongguo Zhong Xi Yi Jie He Za Zhi. 34, 267-271.

Hsin, Y. H., Cheng, C. H., Tzen, J. T., Wu, M. J., Shu, K. H., and Chen, H. C. (2006). Effect of aristolochic acid on intracellular calcium concentration and its links with apoptosis in renal tubular cells. Apoptosis 11, 2167-2177. doi: 10.1007/s10495-006-0289-0

Hu, Y. F., Huang, W. Y., Li, Y. Q., Luo, Y., Jiang, Q., Liang, Y. S., et al. (2019). Mechanism of Rhein on Renal Toxicity of Mice. Chin. J. Exp. Tradit. Med. Formulae. 25, 54-59. doi: 10.13422/j.cnki.syfjx.20190821

Huang, W., and Sun, R. (2010). Pathological Damage Mechanism of Rats'Nephrotoxicity caused by Alcohol Extracted Components of Herba Leonuri. Chin. J. Exp. Tradit. Med. Formulae. 16, 111-114. doi: 10.13422/ j.cnki.syfjx.2010.09.070

Huang, W., Liu, C., Xie, L., Wang, Y., Xu, Y., and Li, Y. (2019). Integrated network pharmacology and targeted metabolomics to reveal the mechanism of nephrotoxicity of triptolide. Toxicol. Res. (Camb). 8, 850-861. doi: 10.1039/ c9tx00067d

Ichimura, T., Asseldonk, E. J., Humphreys, B. D., Gunaratnam, L., Duffield, J. S., and Bonventre, J. V. (2008). Kidney injury molecule-1 is a phosphatidylserine receptor that confers a phagocytic phenotype on epithelial cells. J. Clin. Invest. 118, 1657-1668. doi: 10.1172/JCI34487

Jelaković, B., Dika, Ž., Arlt, V. M., Stiborova, M., Pavlović, N. M., Nikolić, J., et al. (2019). Balkan Endemic Nephropathy and the Causative Role of Aristolochic Acid. Semin. Nephrol. 39, 284-296. doi: 10.1016/j.semnephrol.2019.02.007

Jiao, Y. T., Gao, J., Ren, B., Li, X., Hu, Y., Zhang, W., et al. (2014). Hepatotoxicity and Nephrotoxicity of Chinese Herbal Medicine and Their Countermeasures. World Chin. Med. 9, 124-127. doi: 10.3969/j.issn.1673-7202.2014.01.043

Jing, Y., Zhang, Y. F., Shang, M. Y., Yu, J., Tang, J. W., Liu, G. X., et al. (2017). Phenanthrene derivatives from roots and rhizomes of Asarum heterotropoides var. mandshuricum. Fitoterapia 117, 101-108. doi: 10.1016/j.fitote.2017.01.008

Kashani, K., Al-Khafaji, A., Ardiles, T., Artigas, A., Bagshaw, S. M., Bell, M., et al. (2013). Discovery and validation of cell cycle arrest biomarkers in human acute kidney injury. Crit. Care 17, R25. doi: 10.1186/cc12503

Li, Y. G., and Pan, L. Q. (2012). Mechanism of External Use of High Dose Wuwu Pellet on Rat's Renal Toxicity Apoptosis. J. Nanjing Univer. Chin. Med. 28, 152-155. doi: 10.14148/j.issn.1672-0482.2012.02.018

Li, B., Li, X. M., Zhang, C. Y., Wang, X., and Cai, S. Q. (2004). Cellular mechanism of renal proximal tubular epithelial cell injury induced by aristolochic acid I and aristololactam I. J. Peking Univ. Health Sci. 36, 36-40.

Li, Y., Liu, Z., Guo, X., Shu, J., Chen, Z., and Li, L. (2006). Aristolochic acid Iinduced DNA damage and cell cycle arrest in renal tubular epithelial cells in vitro. Arch. Toxicol. 80, 524-532. doi: 10.1007/s00204-006-0090-4

Li, Z. B., Wang, Z. Q., Gong, C. X., Geng, L. F., Hui, N. L., and Zhu, J. J. (2009). Toxicity-reduced and Action-enhancing Effects of Total Glucosides of Paeony on Tripterygium Glycosides in Treating Lupus Nephritis. Tradit. Chin. Drug Res. Clin. Pharmacol. 20, 513-516. doi: 10.19378/j.issn.1003-9783.2009.06.005 
Li, J., Zhang, L., Jiang, Z. Z., Shu, B., Li, F., Bao, Q. L., et al. (2010). Toxicities of aristolochic acid I and aristololactam I in cultured renal epithelial cells. Toxicol. In Vitro 24, 1092-1097. doi: 10.1016/j.tiv.2010.03.012

Li, X. J., Jiang, Z. Z., and Zhang, L. Y. (2014). Triptolide: progress on research in pharmacodynamics and toxicology. J. Ethnopharmacol. 155, 67-79. doi: 10.1016/j.jep.2014.06.006

Li, A., Ma, N., Zhao, Z., Yuan, M., Li, H., and Wang, Q. (2016). Glycyrrhetinic acid might increase the nephrotoxicity of bakuchiol by inhibiting cytochrome P450 isoenzymes. PeerJ 4, e2723. doi: 10.7717/peerj.2723

Li, W. H., Wang, Y. Z., Luo, S. X., Zhang, Y., Nie, R. J., Sun, Z. Y., et al. (2017). Effect of Long Term Administration of Stri-frying Toosendan Fructus on Liver and Kidney Toxicity of Rats. J. Liaoning Univer. Tradit. Chin. Med. 20, 48-51. doi: 10.13194/j.issn.1673-842x.2018.01.013

Li, J., Zhang, M. C., Mao, Y., Li, Y. M., Zhang, X. X., Peng, X. H., et al. (2018). The potential role of aquaporin 1 on aristolochic acid I induced epithelial mesenchymal transition on HK-2 cells. J. Cell. Physiol. 233, 4919-4925. doi: $10.1002 /$ jcp. 26310

Li, M., Jia, F., Zhou, H., Di, J., and Yang, M. (2018). Elevated aerobic glycolysis in renal tubular epithelial cells influences the proliferation and differentiation of podocytes and promotes renal interstitial fibrosis. Eur. Rev. Med. Pharmacol. Sci. 22, 5082-5090. doi: 10.26355/eurrev_201808_15701

Li, S. H., Pang, G. M., and Dai, W. B. (2018). Retrospective Analysis of 21 Cases of Adverse Reactions Induced by Longdanxiegan Pills. Shenzhen J. Integr. Tradit. Chin. Western Med. 28, 39-41. doi: 10.16458/j.cnki.1007-0893.2018.18.019

Li, L. (2016). Problems and countermeasures in the usage of Chinese patent medicine. Clin. Res. Pract. 1, 128-129. doi: 10.19347/j.cnki.2096-1413.2016.23.074

Liu, P., Wei, H. W., Chang, J. H., Miao, G. X., Liu, X. G., Li, Z. S., et al. (2017). Oral colon-specific drug delivery system reduces the nephrotoxicity of rhubarb anthraquinones when they produce purgative efficacy. Exp. Ther. Med. 14, 3589-3601. doi: 10.3892/etm.2017.4959

Liu, J. (2020). Research Progress on pharmacological effects, toxicity and processing method of cinnabar. Contemp. Med. Forum. 18, 199-201.

Lu, H., Chen, B., Hong, W., Liang, Y., and Bai, Y. (2016). Transforming growth factor- $\beta 1$ stimulates hedgehog signaling to promote epithelial-mesenchymal transition after kidney injury. FEBS. J. 283, 3771-3790. doi: 10.1111/febs.13842

Luo, X., Yang, X., Li, J., Zou, G., Lin, Y. F., Qing, G. Q., et al. (2018a). The procalcitonin/albumin ratio as an early diagnostic predictor in discriminating urosepsis from patients with febrile urinary tract infection. Med. (Baltimore). 97, e11078. doi: 10.1097/MD.0000000000011078

Luo, H. M., Gu, C. Y., Liu, C. X., Wang, Y. M., Wang, H., and Li, Y. B. (2018b). Plasma metabolic profiling analysis of Strychnos nux-vomica Linn. and Tripterygium wilfordii Hook F-induced renal toxicity using metabolomics coupled with UPLC/Q-TOF-MS. Toxicol. Res. (Camb). 7, 1153-1163. doi: 10.1039/c8tx00115d

Luo, Y., Liu, H. Y., Zhou, B. H., and Song, J. C. (2018c). Research of toxicity of Herba Leonuri. Jilin J. Tradit. Chin. Med. 38, 1082-1086. doi: 10.13463/ j.cnki.jlzyy.2018.09.026

Lv, W., Piao, J. H., and Jiang, J. G. (2012). Typical toxic components in traditional Chinese medicine. Expert. Opin. Drug Saf. 11, 985-1002. doi: 10.1517/ 14740338.2012.726610

Ma, L. P., Qin, Y. H., Shen, Z. W., Bi, H. C., Hu, H. Y., Huang, M., et al. (2015). Aristolochic acid I is a substrate of BCRP but not P-glycoprotein or MRP2. J. Ethnopharmacol. 172, 430-435. doi: 10.1016/j.jep.2015.07.011

Masereeuw, R., and Russel, F. G. (2010). Therapeutic implications of renal anionic drug transporters. Pharmacol. Ther. 126, 200-221. doi: 10.1016/j.pharmthera. 2010.02.007

Matsushita, T., Kusakabe, Y., Kitamura, A., Okada, S., and Murase, K. (2011). Investigation of protective effect of hydrogen-rich water against cisplatininduced nephrotoxicity in rats using blood oxygenation level-dependent magnetic resonance imaging. Jpn. J. Radiol. 29, 503-512. doi: 10.1007/s11604-011-0588-4

Nigam, S. K., Bush, K. T., Martovetsky, G., Ahn, S. Y., Liu, H. C., Richard, E., et al. (2015). The organic anion transporter (OAT) family: a systems biology perspective. Physiol. Rev. 95, 83-123. doi: 10.1152/physrev.00025.2013

Nortier, J., Pozdzik, A., Roumeguere, T., and Vanherweghem, J. L. (2015). Aristolochic acid nephropathy ("Chinese herb nephropathy"). Nephrol. Ther. 11, 574-588. doi: 10.1016/j.nephro.2015.10.001

Peterson, P. A., Evrin, P. E., and Berggard, I. (1969). Differentiation of glomerular, tubular, and normal proteinuria: determinations of urinary excretion of beta2- macroglobulin, albumin, and total protein. J. Clin. Invest. 48, 1189-1198. doi: $10.1172 /$ JCI106083

Pianta, T. J., Pickering, J. W., Succar, L., Chin, M., Davidson, T., Buckley, N. A., et al. (2017). Dexamethasone Modifies Cystatin C-Based Diagnosis of Acute Kidney Injury During Cisplatin-Based Chemotherapy. Kidney Blood Press Res. 42, 62-75. doi: 10.1159/000469715

Qu, L., Qu, F., Jia, Z. X., Wang, C. H., Wu, C. H., and Zhang, J. L. (2015). Integrated targeted sphingolipidomics and transcriptomics reveal abnormal sphingolipid metabolism as a novel mechanism of the hepatotoxicity and nephrotoxicity of triptolide. J. Ethnopharmacol. 170, 28-38. doi: 10.1016/ j.jep.2015.05.010

Sborchia, M., De Prez, E. G., Antoine, M. H., Bienfait, L., Indra, R., Valbuena, G., et al. (2019). The impact of p53 on aristolochic acid I-induced nephrotoxicity and DNA damage in vivo and in vitro. Arch. Toxicol. 93, 3345-3366. doi: 10.1007/s00204-019-02578-4

Schaub, S., Wilkins, J. A., Antonovici, M., Krokhin, O., Weiler, T., Rush, D., et al. (2005). Proteomic-based identification of cleaved urinary beta2-microglobulin as a potential marker for acute tubular injury in renal allografts. Am. J. Transpl. 5, 729-738. doi: 10.1111/j.1600-6143.2005.00766.x

Schött, U., Kander, T., and Bentzer, P. (2018). Effects of Dextran-70 and Albumin on Coagulation in Experimental Hemorrhage in the Guinea Pig. Shock 50, 366372. doi: 10.1097/SHK.0000000000001025

Shang, S. L., Cai, G. Y., Duan, S. W., Li, P., Li, Q. G., and Chen, X. M. (2018). Retrospective analysis of tacrolimus combined with Tripterygium wilfordii polyglycoside for treating idiopathic membranous nephropathy. BMC Nephrol. 19, 182. doi: 10.1186/s12882-018-0967-5

Shi, M., Ma, L., Zhou, L., and Fu, P. (2016). Renal Protective Effects of $17 \beta$ Estradiol on Mice with Acute Aristolochic Acid Nephropathy. Molecules 21, 1391. doi: 10.3390/molecules21101391

Singhuber, J., Zhu, M., Prinz, S., and Kopp, B. (2009). Aconitum in traditional Chinese medicine: a valuable drug or an unpredictable risk? J. Ethnopharmacol. 126, 18-30. doi: 10.1016/j.jep.2009.07.031

Slade, N., Moll, U. M., Brdar, B., Zorić, A., and Jelaković, B. (2009). p53 mutations as fingerprints for aristolochic acid: an environmental carcinogen in endemic (Balkan) nephropathy. Mutat. Res. 663, 1-6. doi: 10.1016/j.mrfmmm.2009.01.005

Song, C. Y., Xu, Y. G., and Lu, Y. Q. (2020). Use of Tripterygium wilfordii Hook F for immune-mediated inflammatory diseases: progress and future prospects. J. Zhejiang Univ. Sci. B. 21, 280-290. doi: 10.1631/jzus.B1900607

Stiborová, M., Frei, E., Breuer, A., Wiessler, M., and Schmeiser, H. H. (2001). Evidence for reductive activation of carcinogenic aristolochic acids by prostaglandin $\mathrm{H}$ synthase - (32)P-postlabeling analysis of DNA adduct formation. Mutat. Res. 493, 149-160. doi: 10.1016/s1383-5718(01)00171-1

Stratta, P., Quaglia, M., Airoldi, A., and Aime, S. (2012). Structure-function relationships of iodinated contrast media and risk of nephrotoxicity. Curr. Med. Chem. 19, 736-743. doi: 10.2174/092986712798992084

Sun, X., and Hei, S. E. (1997). Peritoneal dialysis in the treatment of multiple organ damage caused by Xanthium sibiricum poisoning: a case report. Shandong Med. J. 37, 63.

Sun, B., Wang, H., Zhang, L., Yang, X. F., Zhang, M. S., Zhu, X. X., et al. (2018). Role of interleukin 17 in TGF- $\beta$ signaling-mediated renal interstitial fibrosis. Cytokine 106, 80-88. doi: 10.1016/j.cyto.2017.10.015

Sun, X. Q. (2017). Research on Nephrotoxicity of Total Alkaloids of Leonuri Herba and Its Mechanism. Shandong Univer. Tradit. Chin. Med. 20-45.

Tian, Y. H., Yang, Y. H., Gao, L., Zhao, H. J., Peng, X. L., Zhang, Z. W., et al. (2014). Expression of histone deacetylase-1 and p300 in aristolochic acid nephropathy models. Toxicol. Mech. Methods 24, 377-384. doi: 10.3109/ 15376516.2014.920448

Tsai, K. D., Chen, W., Wang, S. H., Yu, W. H., Jhih, Y. C., Hsing, Y. W., et al. (2014). Downregulation of connective tissue growth factor by LPS/IFN- $\gamma$ induced nitric oxide is reversed by aristolochic acid treatment in glomerular mesangial cells via STAT- $1 \alpha$ and NF- $\mathrm{KB}$ signaling. Chem. Biol. Interact. 210, 86-95. doi: 10.1016/j.cbi.2013.12.017

Vanherweghem, J. L., Depierreux, M., Tielemans, C., Abramowicz, D., Dratwa, M., Jadoul, M., et al. (1993). Rapidly progressive interstitial renal fibrosis in young women: association with slimming regimen including Chinese herbs. Lancet 341, 387-391. doi: 10.1016/0140-6736(93)92984-2

Verhagen, H. J., de Leeuw, D. C., Roemer, M. G., Denkers, F., Pouwels, W., Rutten, A., et al. (2014). IGFBP7 induces apoptosis of acute myeloid leukemia cells and 
synergizes with chemotherapy in suppression of leukemia cell survival. Cell. Death. Dis. 5, e1300. doi: 10.1038/cddis.2014.268

Vinken, P., Starckx, S., Barale-Thomas, E., Looszova, A., Sonee, M., Goeminne, N., et al. (2012). Tissue Kim-1 and urinary clusterin as early indicators of cisplatininduced acute kidney injury in rats. Toxicol. Pathol. 40, 1049-1062. doi: $10.1177 / 0192623312444765$

Wang, C. W., and Liu, W. H. (2009). Renal Lesion Induced by Oral Preparations of Traditional Chinese Medicines: Analysis of 619 Cases. China Pharm. 20, 11871188 .

Wang, S. F., Liu, Y. C., Wang, H. Y., Li, J. J., and Zhou, Z. Z. (1996). Clinical observation on nephrotoxicity of $T$. regelii Sprague. et Takeda. China J. Chin. Mater. Med. 21, 52-54.

Wang, M., Chen, H. Y., Hu, X. X., and Lu, P. (1999). Analysis of causes of death in 83 cases of T. regelii Sprague. et Takeda poisoning. Lishizhen Med. Mater. Med. Res. 10, 3-5.

Wang, Q. X., Wu, C. Q., Zhou, L., Yang, B. H., Wang, Q. J., Shi, C., et al. (2010). Apoptosis mechanisms induced by emodin in HK-2 cells. Chin. J. New Drugs 19, 2034-2038 +2044. doi: 10.1016/j.tiv.2014.10.021

Wang, Y., Han, T., Xue, L. M., Han, P., Zhang, Q. Y., Huang, B. K., et al. (2011). Hepatotoxicity of kaurene glycosides from Xanthium strumarium L. fruits in mice. Pharmazie 66, 445-449. doi: 10.1691/ph.2011.0844

Wang, M., Qu, J. T., Dai, B., and Mei, C. L. (2013). Fructus Xanthii Poisoning: A Case Report and Literature Review. Chin. Gen. Pract. 16, 218-220. doi: 10.3969/j.issn.1007-9572.2013.01.070

Wang, Y., Wang, D. P., Wu, J., Wang, B. H., Gao, X. H., Wang, L. J., et al. (2015a). Cinnabar-induced subchronic renal injury is associated with increased apoptosis in rats. Biomed. Res. Int. 2015, 278931. doi: 10.1155/2015/278931

Wang, Y., Wang, D. P., Wu, J., Wang, B. H., Wang, L. J., Gao, X., et al. (2015b). Cinnabar induces renal inflammation and fibrogenesis in rats. Biomed. Res. Int. 2015, 280958. doi: 10.1155/2015/280958

Wang, L. M., Ding, X. S., Li, C. Y., Zhao, Y., Yu, C. G., Yi, Y., et al. (2018). Oral administration of Aristolochia manshuriensis Kom in rats induces tumors in multiple organs. J. Ethnopharmacol. 225, 81-89. doi: 10.1016/j.jep.2018. 07.001

Wang, J. J., Chi, L., Wang, W. J., Ba, Y. Y., Li, J., Zhang, Y. T., et al. (2019). Influence of Shenling Baizhu Powder on mRNA expression of NLRP3, NF- $\mathrm{kB}$, MUC2, TFF3 in rats of ulcerative colitis. World J. Integr. Tradit. Western Med. 14, 1638-1641. doi: 10.13935/j.cnki.sjzx.191202

Wang, J. L. (2013). Development status and Prospect of traditional Chinese medicine in the world. Ability Wisdom (32), 352-353.

Waring, W. S., and Moonie, A. (2011). Earlier recognition of nephrotoxicity using novel biomarkers of acute kidney injury. Clin. Toxicol. (Phila). 49, 720-728. doi: $10.3109 / 15563650.2011 .615319$

Wei, X. Y., Qiu, Z. D., Chen, J. L., Sun, R. Q., Huang, L. Q., and Lai, C. J. (2019). Research advancement in mechanisms of processing and compatibility for detoxication of Aconitums. Zhongguo Zhong Yao Za Zhi. 44, 3695-3704. doi: 10.19540/j.cnki.cjcmm.20190629.301

Wen, Y. J., Su, T., Tang, J. W., Zhang, C. Y., Wang, X., Cai, S. Q., et al. (2006). Cytotoxicity of phenanthrenes extracted from Aristolochia Contorta in human proximal tubular epithelial cell line. Nephron. Exp. Nephrol. 103, 95-102. doi: $10.1159 / 000092194$

Wen, S. J., Wang, C. Y., Huo, X. K., Meng, Q., Liu, Z. H., Yang, S. L., et al. (2018). JBP485 attenuates vancomycin-induced nephrotoxicity by regulating the expressions of organic anion transporter (Oat) 1, Oat3, organic cation transporter 2 (Oct2), multidrug resistance-associated protein 2 (Mrp2) and P-glycoprotein (P-gp) in rats. Toxicol. Lett. 295, 195-204. doi: 10.1016/ j.toxlet.2018.06.1220

Weng, Z., Zeng, F., Zhu, Z., Qian, D. W., Guo, S., Wang, H. Q., et al. (2018). Comparative analysis of sixteen flavonoids from different parts of Sophora flavescens Ait. by ultra-high-performance liquid chromatography-tandem mass spectrometry. J. Pharm. Biomed. Anal. 156, 214-220. doi: 10.1016/ j.jpba.2018.04.046

Wu, S. H. (1964). Acute renal failure caused by Aristolochia manshuriensis Kom: a report of 2 cases. Jiangsu J. Tradit. Chin. Med. 5, 12-13.

Xi, C., Peng, S. J., Wu, Z. P., Zhou, Q. P., and Zhou, J. (2017). Toxicity of triptolide and the molecular mechanisms involved. Biomed. Pharmacother. 90, 531-541. doi: 10.1016/j.biopha.2017.04.003
Xiang, X. X., Tang, D. X., Xiong, J. Y., Liang, Y. J., Mou, D. H., Yang, X. W., et al. (2012). Study on the Effect of Ethanol Extraction of Melia toosendan on Blood Biochemistry and Cytology of Rats. J. Sichuan Tradit. Chin. Med. 30, 62-65.

Xing, C. K., Wu, J. F., Zhang, J., Zhang, W. J., Li, J. L., Li, Y., et al. (2013). Changes of TFF3 mRNA in Rat's Spleen during the Healing of Gastric Ulcer. J. Hebei North Univer. (Natural Sci. Edition) 29, 62-64+68+117. doi: 10.3969/ j.issn.1673-1492.2013.02.016

Yamamoto, T., Noiri, E., Ono, Y., Doi, K., Negishi, K., Kamijo, A., et al. (2007). Renal L-type fatty acid binding protein in acute ischemic injury. J. Am. Soc Nephrol. 18, 2894-2902. doi: 10.1681/ASN.2007010097

Yan, M., Zhang, L. Y., Sun, L. X., Jiang, Z. Z., and Xiao, X. H. (2006). Nephrotoxicity study of total rhubarb anthraquinones on Sprague Dawley rats using DNA microarrays. J. Ethnopharmacol. 107, 308-311. doi: 10.1016/j.jep.2006.03.031

Yang, F., Zhuo, L., Ananda, S., Sun, T., Li, S., and Liu, L. (2011). Role of reactive oxygen species in triptolide-induced apoptosis of renal tubular cells and renal injury in rats. J. Huazhong. Univ. Sci. Technolog. Med. Sci. 31, 335-341. doi: 10.1007/s11596-011-0377-4

Yang, H. Y., Dou, Y., Zheng, X. H., Tan, Y., Cheng, J. J., Li, L., et al. (2011). Cysteinyl leukotrienes synthesis is involved in aristolochic acid I-induced apoptosis in renal proximal tubular epithelial cells. Toxicology 287, 1-3. doi: 10.1016/j.tox.2011.05.014

Yang, H. Y., Yang, C. C., Wu, C. Y., Wang, L. J., and Lu, K. L. (2019). Aristolochic Acid and Immunotherapy for Urothelial Carcinoma: Directions for unmet Needs. Int. J. Mol. Sci. 20, 3162. doi: 10.3390/ijms20133162

Yang, X., Liu, C. X., Yuan, F. L., Wang, W. X., He, T., Han, S., et al. (2019). Mechanism of renal injury in rats induced by Phytolaccae Radix based on network toxicology. Chin. Tradit. Herb. Drugs 50, 4974-4984. doi: 10.7501/ j.issn.0253-2670.2019.20.020

Ye, Z. B., Xu, J., Li, Z., and Lu, G. C. (2003). Abnormal prostaglandin production in pathogenesis of chronic renal failure induced by cane of Aristolochia manshuriensis. Chin. Tradit. Herb. Drugs 34, 149.

Yi, J. H., Han, S. W., Kim, W. Y., Kim, J., and Park, M. H. (2018). Effects of aristolochic acid I and/or hypokalemia on tubular damage in C57BL/6 rat with aristolochic acid nephropathy. Korean J. Intern. Med. 33, 763-773. doi: 10.3904/kjim.2016.097

Yin, G., Liu, Z. Z., Liu, Z. H., Hu, W. X., Zeng, C. H., Chen, H. P., et al. (2010). Clinical and pathological features in patients with aristolochic acid nephropathy caused by different drug type and different dosage of Mutong. J. Chin. Pract. Diagnosis Ther. 24, 664-667.

Yin, D. D., Luo, J. H., Zhao, Z. Y., Liao, Y. J., and Li, Y. (2018). Tranilast prevents renal interstitial fibrosis by blocking mast cell infiltration in a rat model of diabetic kidney disease. Mol. Med. Rep. 17, 7356-7364. doi: 10.3892/mmr.2018.8776

Yu, S. X., Zhang, C. X., Chen, C. Y., Yan, R. Y., Yang, B., Liao, C. L., et al. (2010). Effects of primary processing on quality of cortex Magnolia officinalis. Zhongguo Zhong Yao Za Zhi 35, 1831-1835. doi: 10.4268/cjcmm20101414

Zeng, W., Gu, G. H., Li, J. X., Ying, W. H., and Yuan, J. S. (2015). Study of Renal Toxicity on Arecoline. J. Tradit. Chin. Med. Univer. Hunan. 35, 6-8+73. doi: 10.3969/j.issn.1674-070X.2015.06.003

Zhang, P. R., and Wang, M. X. (1985). A case report of mercury poisoning caused by cinnabar [J]. Chin. J. Integr. Tradit. Western Med. 8, 471.

Zhang, C., Chen, Y. P., Dong, H. R., and Qiu, C. B. (2005). The therapeutic effects of bosentan and valsartan on renal interstitial fibrosis of chronic aristolochic acid nephropathy. Chin. Med. J. 85, 2601-2606.

Zhang, Q. Q., Wang, A. P., and Jin, H. T. (2013). Research progress on nephrotoxicity of Chinese materia medica. Pharm. J. Chin. PLA. 29, 558561. doi: 10.3969/j.issn.1008-9926.2013.06.023

Zhang, L., Yang, Z. C., Gu, Y. Q., Qian, Z. Z., and Zhou, L. L. (2015). Study of Aristolochic Acid I in Activating p38 MAPK Pathway and Leading to Renalcell Apoptosis in Rat's Renal Tissue. Chin. J. N. Drugs Clin. Rem. 26, 576-581. doi: 10.3969/j.issn.1003-9783.2014.05.002

Zhang, C., Fan, L., Fan, S., Wang, J. Q., Luo, T., Tang, Y., et al. (2019). Cinnamomum cassia Presl: A Review of Its Traditional Uses, Phytochemistry, Pharmacology and Toxicology. Molecules 24, 3473. doi: 10.3390/molecules24193473

Zhang, S. J., Zhang, Y. G., Xin, E. D., Zhang, A. X., Niu, J. T., Bian, T. T., et al. (2020). Effects of traditional Chinese medicine processing on chemical constituents and pharmacological action of traditional Chinese medicine. J. Tradit. Chin. Vet. Med. 39, 40-42. doi: 10.13823/j.cnki.jtcvm.2020.02.010 
Zhou, L. L., Zhou, C., Liang, X. W., Feng, Z., Liu, Z. P., Wang, H. L., et al. (2017). Selfprotection against triptolide-induced toxicity in human hepatic cells via Nrf2-ARENQO1 pathway. Chin. J. Integr. Med. 23, 929-936. doi: 10.1007/s11655-017-2546-6

Zhou, Y. Z., Zhao, L. D., Chen, H., Zhang, Y., Wang, D. F., Huang, L. F., et al. (2018). Comparison of the impact of Tripterygium wilfordii Hook F and Methotrexate treatment on radiological progression in active rheumatoid arthritis: 2-year follow up of a randomized, non-blinded, controlled study. Biomed. Central 20, 70. doi: 10.1186/s13075-018-1563-6

Zhu, Y. F., Chen, Y. P., Rui, H. L., Dong, H. R., and Hu, Z. (2007). Protective effects of Hirsutella sinensis on renal interstitial fibrosis: experiment with rat model of chronic aristolochic acid nephropathy. Chin. Med. J. 87, 2667-2671.

Zhu, T. T., Liu, X., Wang, X. L., Cao, G., Qin, K. M., Pei, K., et al. (2016). Profiling and analysis of multiple compounds in rhubarb decoction after processing by wine steaming using UHPLC-Q-TOF-MS coupled with multiple statistical strategies. J. Sep. Sci. 39, 3081-3090. doi: 10.1002/jssc.201600256

Conflict of Interest: The authors declare that the research was conducted in the absence of any commercial or financial relationships that could be construed as a potential conflict of interest.

Copyright $\odot 2020 \mathrm{Xu}$, Zhu, Ying, Zhao, Wu, Cao and Wang. This is an open-access article distributed under the terms of the Creative Commons Attribution License (CC BY). The use, distribution or reproduction in other forums is permitted, provided the original author(s) and the copyright owner(s) are credited and that the original publication in this journal is cited, in accordance with accepted academic practice. No use, distribution or reproduction is permitted which does not comply with these terms. 